\title{
PEMANFAATAN ECENG GONDOK FERMENTASI SEBAGAI PAKAN DOMBA LOKAL JANTAN LEPAS SAPIH
}

\section{(Utilization of Fermented Water Hyacinth as a Feed on Weaning Local Male Sheep)}

\author{
Nurtati Natalia Nababan ${ }^{1}$, Tri Hesti Wahyuni ${ }^{2}$ dan Nevy Diana Hanafi ${ }^{2}$ \\ 1. Mahasiswa Program Studi Peternakan Fakultas Pertanian Universitas Sumatera Utara \\ 2. Staf Pengajar Program Studi Peternakan Fakultas Pertanian Universitas Sumatera Utara
}

\begin{abstract}
Water hyacinth is a plant that can be used in animal feed sheep through fermentation process. This research aims to determine the effect of water hyacinth fermented with local microorganisms and Trichoderma harzianum on feed consumption, average daily gain (ADG) and feed conversion ratio (FCR) on weaning local male sheep. The experiment was conducted at the Laboratory of Animal Biology, Animal Husbandry Program, Agricultural Faculty, University of Sumatera Utara in August to November 2013 using 20 local male sheep with

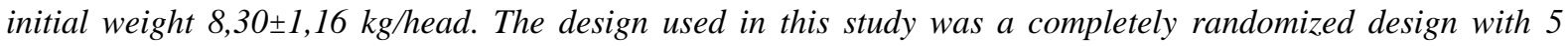
treatments and 4 replications. This treatment consists of $P_{0}$ (concentrate $+100 \%$ grass $) ; P_{1}$ (concentrate +40 $\%$ grass $+60 \%$ fermented water hyacinth MOL); $P_{2}$ (concentrate $+40 \%$ grass $+60 \%$ fermented water hyacinth Trichoderma harzianum); $P_{3}$ (concentrate $+100 \%$ fermented water hyacinth MOL); $P_{4}$ (concentrate $+100 \%$ fermented water hyacinth Trichoderma harzianum) respectively. The results showed had not significant different $(P>0.05)$ and that average for feed consumption ( $g /$ head/day) for treatments $P_{0}, P_{1}, P_{2}, P_{3}$ and $P_{4}$, respectively were 472,04; 425,27,11; 433,93; 435,12 and 402,69 respectively. Average daily gain (ADG) (g/head/day) 28,10; 28,72; 28,57; 28,24 and 28,93 respectively. Average feed convertion ratio (FCR) 16,79; 14,83; 15,12; 15,39 and 13,95 respectively. Utilization of water hyacinth fermentation MOL and Trichoderma harzianum nonsigninificant differently on feed consumption, average daily gain and feed conversion ratio of weaning local male sheep for 4 months.
\end{abstract}

Keywords: Water hyacinth, local microorganisms, Trichoderma harzianum, local sheep (Ovis aries) male, fermentation

\begin{abstract}
ABSTRAK
Eceng gondok merupakan tanaman gulma yang dapat digunakan sebagai bahan pakan ternak domba melalui proses fermentasi. Penelitian ini bertujuan untuk mengetahui pengaruh pemberian eceng gondok yang difermentasi MOL dan Trichoderma harzianum terhadap konsumsi, pertambahan bobot badan dan konversi pakan domba lokal jantan lepas sapih. Penelitian dilaksanakan di Laboratorium biologi ternak, Fakultas Pertanian, Universitas Sumatera Utara pada bulan Agustus-November 2013 yang menggunakan 20 ekor domba

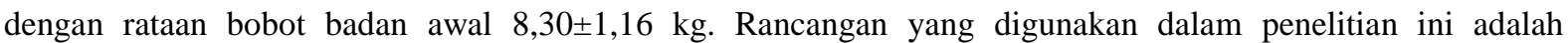
rancangan acak lengkap (RAL) dengan 5 perlakuan dan 4 ulangan. Perlakuan ini terdiri atas $\mathrm{P}_{0}$ (konsentrat + $100 \%$ rumput); $\mathrm{P}_{1}$ (konsentrat $+40 \%$ rumput $+60 \%$ eceng gondok fermentasi MOL); $\mathrm{P}_{2}$ (konsentrat $+40 \%$ rumput+ $60 \%$ eceng gondok fermentasi Trichoderma harzianum); $\mathrm{P}_{3}$ (konsentrat $+100 \%$ eceng gondok fermentasi MOL); P4 (konsentrat $+100 \%$ eceng gondok fermentasi Trichoderma harzianum). Hasil penelitian menunjukkan tidak berbeda nyata $(\mathrm{P}>0,05)$, dimana rataan konsumsi pakan (g/ekor/hari) dengan perlakuan $\mathrm{P}_{0}$, $\mathrm{P}_{1}, \mathrm{P}_{2}, \mathrm{P}_{3}$ dan $\mathrm{P}_{4}$ adalah 472,04; 425,27; 433,93; 435,12 dan 402,69. Rataan pertambahan bobot badan (g/ekor/hari) 28,10; 28,72; 28,57; 28,24 dan 28,93. Rataan konversi pakan 16,79; 14,83; 15,12; 15,39 dan 13,95. Pemanfaatan eceng gondok fermentasi MOL dan Trichoderma harzianum tidak memberikan pengaruh yang nyata terhadap konsumsi pakan, pertambahan bobot badan dan konversi pakan pada domba lokal jantan lepas sapih selama 4 bulan.
\end{abstract}

Kata kunci: Eceng gondok, mikroorganisme lokal, Trichoderma harzianum, domba lokal (Ovis aries) jantan, fermentasi 


\section{PENDAHULUAN}

Perkembangan usaha penggemukan domba didorong oleh permintaan daging untuk konsumsi dalam negeri yang terus meningkat dari tahun ke tahun. Kenaikan konsumsi daging disebabkan oleh peningkatan jumlah penduduk dan kesadaran masyarakat akan pentingnya protein hewani. Tingkat konsumsi daging nasional sebesar 1.817,03 ton pada tahun 2005 dan meningkat menjadi 2.070,24 ton pada tahun 2006. Produksi daging dalarn negeri yang tidak mencukupi kebutuhan daging nasional menyebabkan import daging dari luar negeri. Import daging dari tahun 2005 sampai dengan 2006 mengalami peningkatan dari 519,7 ton menjadi 829,6 ton (Ditjend Bina Produksi Peternakan, 2006).

Domba merupakan salah satu komoditi petemakan yang turut serta memasok ketersediaan daging di dalam negeri. Daging yang tersedia diharapkan tidak hanya dalam jumlah yang cukup tetapi juga dengan kualitas yang lebih baik. Hal ini dapat dicapai salah satunya dengan manajemen pemberian pakan yang lebih baik. Pakan hijauan merupakan sumber pakan utama yang sering diberikan pada temak. Hijauan di Indonesia pada umumnya mempunyai kualitas yang rendah sehingga kurang mampu mendukung produktivitas temak yang maksimal karena penyediaan energi, protein dan mineral tidak mencukupi.

Eceng gondok merupakan salah satu jenis tanaman air yang banyak tumbuh disungaisungai, aliran air, pematang sawah maupun di waduk-waduk. Keberadaan tanaman ini dianggap sebagai gulma karena tanaman ini dapat menyebabkan pendangkalan sungai dan waduk, serta menyebabkan pengurangan atau penguapan air dari unsur hara yang cukup besar. Eceng gondok tumbuh dengan cepat sehingga perlu dilakukan upaya untuk menanganinya agar tidak mengganggu dan merusak lingkungan. Salah satu alternatifnya adalah dimanfaatkan sebagai bahan pakan (Dodiandri, 1997).

Salah satu upaya untuk meningkatkan kandungan nutrisi dari eceng gondok adalah dengan melakukan fermentasi. Pada saat ini teknologi fermentasi yang sangat sederhana serta biayanya murah adalah fermentasi dengan mikroorganisme lokal. Mikroorganisme lokal yang dimaksud adalah Rhizopus sp (ragi tempe), Saccharomyces sp (ragi tape) dan Lactobacillus sp (yoghurt). Teknologi ini sangat sederhana karena sangat praktis, selain itu pengolahannya dapat dilakukan di rumah, karena masyarakat dapat membiakkan sendiri mikroorganisme tersebut dengan cara sederhana. Dalam metode ini dimanfaatkan mikroorganisme yang baik dan mudah didapat dan biayanya yang sangat murah sehingga hasil fermentasi sesuai dengan harapan mampu memperbaiki kandungan nutrisi eceng gondok dan menghancurkan zat anti nutrisi yang terdapat pada eceng gondok. 
Selain mikroorganisme lokal, ada juga fermentator yang sering digunakan oleh para peneliti yaitu Trichoderma harzianum. Trichoderma harzianum banyak dijumpai pada tanaman baik yang sudah lapuk maupun yang masih hidup. Fungi jenis ini mempunyai potensi untuk mengolah selulosa tanaman yang lebih besar. Selulosa dari tanaman dapat berperan sebagai bahan penghasil bioetanol alami dari alam. Jenis fungi ini sudah banyak tersedia secara komersil dan apabila ingin menggunakan dalam jumlah yang banyak dapat dilakukan pembiakan sendiri. Adapun tujuan dari penelitian ini adalah mengetahui pengaruh pemberian eceng gondok yang difermentasi MOL dan Trichoderma harzianum terhadap performans (konsumsi, pertambahan bobot badan dan konversi pakan) domba lokal jantan lepas sapih.

\section{BAHAN DAN METODE PENELITIAN}

\section{Lokasi dan Waktu Penelitian}

Penelitian dilaksanakan di Laboratorium Biologi Ternak Program Studi Peternakan Fakultas Pertanian Universitas Sumatera Utara. Penelitian ini telah berlangsung selama 4 bulan dimulai dari bulan Agustus sampai dengan bulan November 2013.

\section{Bahan dan Alat Penelitian}

Bahan yang digunakan yaitu domba lokal jantan lepas sapih sebanyak 20 ekor dengan rataan bobot badan awal 8,30 $\pm 1,16 \mathrm{~kg}$, pakan konsentrat yang terdiri dari bungkil inti sawit (37\%), dedak padi (25\%), bungkil kedelai (12\%), bungkil kelapa (13\%), urea (3\%), molasses $(6 \%)$, mineral $(2 \%)$ dan garam (2\%). Eceng gondok fermentasi (500 kg) sebagai bahan pakan. Gula pasir $(1,5 \mathrm{~kg})$, youghurt $( \pm 30 \mathrm{cc})$, ragi tempe $(60 \mathrm{~g})$ dan tape $(60 \mathrm{~g})$ sebagai fermentator pembuatan MOL, Trichoderma harzianum (500 g) sebagai fermentator kedua, rodalon sebagai desinfektan dan air minum yang diberikan serta obat-obatan seperti obat cacing (kalbazen) dan anti bloat untuk obat gembung.

Alat yang digunakan yaitu kandang 20 unit dengan ukuran 1 x $0,5 \mathrm{~m}$ beserta perlengkapannya, tempat pakan (ember) sebanyak 20 buah, tempat minum sebanyak 20 buah, timbangan untuk menimbang bobot hidup berkapasitas $50 \mathrm{~kg}$ dengan kepekaan $2 \mathrm{~kg}$, timbangan berkapasitas $2 \mathrm{~kg}$ dengan kepekaan $1 \mathrm{~g}$ untuk menimbang pakan, grinder digunakan untuk menghaluskan bahan pakan konsentrat, coper untuk mencoper bahan pakan, termometer digunakan untuk mengetahui suhu didalam dan diluar kandang, alat penerangan 
kandang, autoklap untuk mensterilkan bahan, alat pembersih kandang dan alat tulis untuk menulis data.

\section{Metode Penelitian}

Metode penelitian yang digunakan adalah rancangan acak lengkap (RAL) dengan 5 perlakuan dan 4 ulangan yaitu:

P0: Konsentrat $+100 \%$ Rumput

P1: Konsentrat $+(40 \%$ Rumput $+60 \%$ eceng gondok fermentasi MOL $)$

P2: Konsentrat $+(40 \%$ Rumput $+60 \%$ eceng gondok fermentasi Trichoderma harzianum $)$

P3: Konsentrat $+100 \%$ eceng gondok fermentasi MOL

P4: Konsentrat $+100 \%$ eceng gondok fermentasi Trichoderma harzianum

Tabel 1. Hasil analisis eceng gondok fermentasi

\begin{tabular}{|c|c|c|c|c|c|c|}
\hline Nama Sampel & $\mathrm{BK} \%$ & LK\% & SK\% & PK\% & $\mathrm{Abu} \%$ & KA\% \\
\hline Eceng Gondok Fermentasi $\mathrm{MOL}^{\mathrm{a}}$ & 92,24 & 2,82 & 22,41 & 9,79 & 13,32 & 7,76 \\
\hline $\begin{array}{l}\text { Eceng Gondok Fermentasi Trichoderma } \\
\text { harzianum }^{\mathrm{b}}\end{array}$ & 92,63 & 2,55 & 22,55 & 19,59 & 22,55 & 7,37 \\
\hline
\end{tabular}

Keterangan: a. Laboratorium Ilmu Makanan Ternak Program studi Peternakan Fakultas Pertanian USU, 2013. b. Loka Penelitian Kambing Potong Sei Putih, 2013.

Tabel 2. Komposisi konsentrat yang digunakan

\begin{tabular}{lccccccccc}
\hline Nama bahan & \%Bahan & Harga/kg & PK & EM & SK & LK & Ca & P & TDN \\
\hline BIS & 37 & 2000 & 15,4 & 2810 & 16,9 & 2,4 & 0,56 & 0,84 & 81,00 \\
Dedak & 25 & 2000 & 12 & 1630 & 13 & 0,5 & 0,1 & 1,5 & 67,00 \\
B. Kedelai & 12 & 7000 & 42 & 2240 & 15,4 & 1,5 & 0,32 & 0,65 & 75,00 \\
Urea & 3 & 2500 & 1,01 & 0 & 0 & 0 & 0 & 0 & 54,00 \\
Molases & 6 & 2000 & 3,4 & 2330 & 0,38 & 0,08 & 1,5 & 0,02 & 81,00 \\
Mineral & 2 & 8000 & 0 & 0 & 0 & 0 & 50 & 25 & 0,00 \\
Garam & 2 & 2000 & 0 & 0 & 0 & 0 & 0 & 0 & 0,00 \\
B. Kelapa & 13 & 3500 & 17 & 1540 & 15 & 1,8 & 0,2 & 0,6 & 79,00 \\
\hline
\end{tabular}

Total 100

\begin{tabular}{lcccccccc}
\hline Nama bahan & Harga/kg & PK & EM & SK & LK & Ca & P & TDN \\
\hline BIS & 740 & 5,69 & 1039,70 & 6,253 & 0,88 & 0,20 & 0,31 & 29,97 \\
Dedak & 500 & 3,00 & 407,5 & 3,25 & 0,12 & 0,02 & 0,37 & 16,75 \\
B. Kedelai & 840 & 5,04 & 268,80 & 1,84 & 0,18 & 0,03 & 0,07 & 9 \\
Urea & 75 & 0,03 & 0 & 0 & 0 & 0 & 0 & 1,62 \\
Molases & 120 & 0,20 & 139,80 & 0,02 & 0,004 & 0,09 & 0,001 & 4,86 \\
Mineral & 160 & 0 & 0 & 0 & 0 & 1 & 0,5 & 0 \\
Garam & 40 & 0 & 0 & 0 & 0 & 0 & 0 & 0 \\
B.Kelapa & 455 & 2,21 & 200,2 & 1,95 & 0,23 & 0,026 & 7,8 & 0 \\
\hline \multicolumn{1}{c}{ Total } & 2930 & 16,18 & 2056 & 13,32 & 1,43 & 1,38 & 9,06 & 62,20 \\
\hline
\end{tabular}

Sumber: Laboratorium Ilmu Makanan Ternak Program studi Peternakan Fakultas Pertanian USU, 2009. 
Metode matematika percobaan yang digunakan adalah:

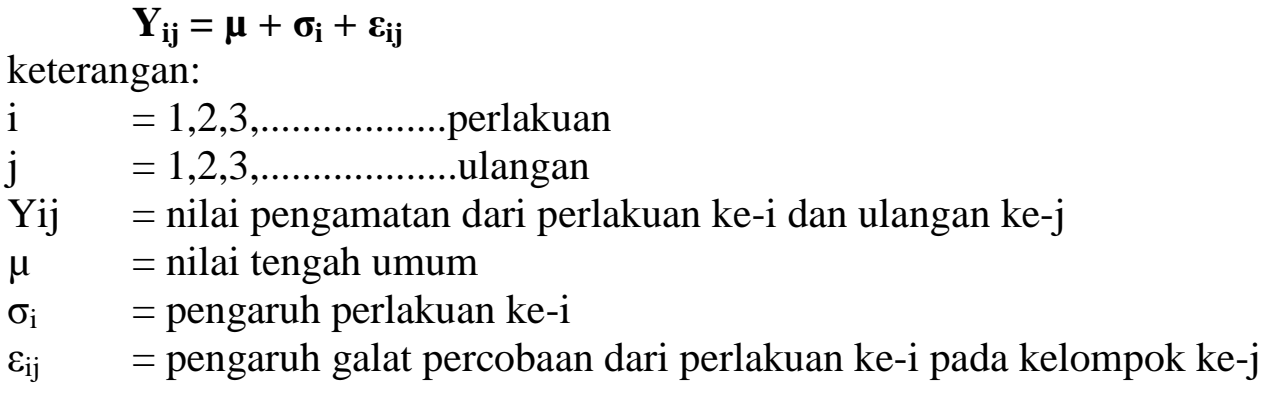

\section{Analisis Data}

Untuk mengetahui pengaruh perlakuan terhadap peubah yang diukur, data yang diperoleh dianalisis dengan sidik ragam, dan dilanjutkan dengan uji beda nyata terkecil (BNT) (Steel dan Torrie, 1993).

\section{Kaidah Keputusan}

- Bila $\mathrm{F}_{\text {hit }}<\mathrm{F}_{0,05} \longrightarrow$ perlakuan tidak berbeda nyata (terima $\mathrm{H} 0 /$ tolak H1).

- Bila $\mathrm{F}_{\text {hit }} \geq \mathrm{F}_{0,05} \longrightarrow$ perlakuan berbeda nyata (tolak $\mathrm{H} 0 /$ trima $\mathrm{H} 1$ )

- Bila $\mathrm{F}_{\text {hit }} \geq \mathrm{F}_{0,05} \longrightarrow$ perlakuan berbeda sangat nyata (tolak H0/terima H1)

\section{Parameter Penelitian}

\section{Konsumsi Pakan}

Konsumsi pakan dihitung setiap hari berdasarkan jumlah pakan yang diberikan pada pagi hari pukul 08.00 Wib dikurangi dengan sisa pakan pada sore hari pukul $17.00 \mathrm{Wib}$. Konsumsi dapat dirumuskan sebagai berikut:

Konsumsi Pakan $=$ Pakan yang diberikan $($ dalam \% BK $)-$ Pakan yang sisa $\quad($ dalam \% BK $)$ (Sodiq dan Abidin, 2002).

\section{Pertambahan Bobot Badan Harian (PBBH)}

Pertambahan bobot badan dihitung dengan cara membagi selisih bobot badan (Bobot akhir - bobot awal) dengan lama hari penimbangan. Dilakukan selama dua minggu sekali, dinyatakan dalam gram per ekor per hari.

$$
\mathrm{PBBH}=\frac{\text { bobot akhir }- \text { bobot awal (g/ekor) }}{\text { lama pemeliharaan (hari) }}
$$

(Sodiq dan Abidin, 2002). 


\section{Konversi Pakan}

Konversi pakan dihitung dengan cara membagi angka rata-rata konsumsi bahan kering per ekor per hari dengan angka rata-rata produksi pertambahan bobot badan per ekor per hari.

$$
\text { Konversi pakan }=\frac{\text { Pakan yang dikonsumsi }(\mathrm{g} / \mathrm{hari})}{\mathrm{PBBH}(\mathrm{g} / \mathrm{hari})}
$$

(Sodiq dan Abidin, 2002).

\section{HASIL DAN PEMBAHASAN}

Rataan dari ketiga parameter penelitian yaitu: konsumsi pakan, pertambahan bobot badan dan konversi pakan selama penelitian dapat dilihat pada Tabel 3 berikut ini. Tabel 3. Rekapitulasi Hasil Penelitian

\begin{tabular}{cccc}
\hline Perlakuan & $\begin{array}{c}\text { Konsumsi Pakan } \\
(\mathrm{g} / \text { ekor/hari })\end{array}$ & $\begin{array}{c}\text { Pertambahan bobot } \\
\text { badan }(\mathrm{g} / \mathrm{ekor} / \mathrm{hari})\end{array}$ & Konversi pakan \\
\hline P0 & $472,04 \pm 64,33^{\text {tn }}$ & $28,10 \pm 2,31^{\text {tn }}$ & $16,79 \pm 1,33^{\text {tn }}$ \\
P1 & $425,27 \pm 48,43^{\text {tn }}$ & $28,72 \pm 3,17^{\text {tn }}$ & $14,83 \pm 1,07^{\text {tn }}$ \\
P2 & $433,93 \pm 76,15^{\text {tn }}$ & $28,57 \pm, 1,44^{\text {tn }}$ & $15,12 \pm 1,95^{\text {tn }}$ \\
P3 & $435,12 \pm 41,14^{\text {tn }}$ & $28,24 \pm 0,66^{\text {tn }}$ & $15,39 \pm 1,13^{\text {tn }}$ \\
P4 & $402,69 \pm 75,69^{\text {tn }}$ & $28,93 \pm 1,89^{\text {tn }}$ & $13,95 \pm 1,97^{\text {tn }}$ \\
\hline
\end{tabular}

Keterangan: $\mathrm{tn}=$ tidak berbeda nyata

\section{Konsumsi Pakan}

Berdasarkan nilai rataan konsumsi yang diperoleh pada Tabel 3 yaitu 434,36 g/ekor/hari yang apabila dipersenkan dalam bahan kering maka diperoleh hasil 2,07\% dari bobot badan, yaitu hasil ini tidak mencapai standar untuk konsumsi pakan dalam bahan kering seperti yang dikatakan oleh Parakkasi (1999) yang menyatakan bahwa standar konsumsi dalam bahan kering untuk ternak ruminansia adalah 3-5\% dari bobot badan.

Pemberian eceng gondok yang difermentasi MOL dan Ttrichoderma harzianum sebagai pakan domba lokal jantan lepas sapih memberikan pengaruh yang tidak berbeda nyata $(\mathrm{P}>0,05)$ terhadap konsumsi pakan. Adanya pengaruh yang tidak berbeda nyata ini menunjukkan bahwa pemberian eceng gondok baik yang difermentasi MOL ataupun Trichoderma harzianum memberikan hasil yang sama baiknya dengan pemberian rumput.

Berdasarkan rataan konsumsi pakan pada Tabel 3 yaitu 434,36 g/ekor/hari dapat diasumsikan bahwa pemberian eceng gondok yang difermentasi MOL dan Trichoderma 
harzianum memberikan hasil yang sama baiknya dengan rumput. Hal ini diakibatkan oleh rumput kolonjono yang memiliki lebih banyak batang dibandingkan daun dan aroma eceng gondok fermentasi yang kurang baik sehingga menyebabkan tingkat palatabilitas rendah, yaitu dapat dilihat bahwa kualitas dan tingkat palatabilitas sangat mempengaruhi konsumsi pakan. Hal ini sesuai dengan pernyataan Piliang (2000) yang menyatakan bahwa konsumsi dipengaruhi beberapa faktor diantaranya adalah palatabilitas pakan, bentuk fisik pakan, bobot badan, jenis kelamin, temperatur lingkungan, keseimbangan hormonal dan fase pertumbuhan. Hal ini juga sesuai dengan pernyataan Williamson and Payne (1995) yang menyatakan bahwa pengukuran konsumsi pakan dipengaruhi oleh perbedaan ternak, palatabilitas pakan dan seleksi terhadap hijauan pakan. Konsumsi pakan juga mempunyai hubungan dengan kebutuhan energi ternak yang sering menyebabkan konsumsi pakan ternak menjadi berbeda.

\section{Pertambahan Bobot Badan}

Berdasarkan Tabel 3 dapat dilihat rataan pertambahan bobot badan selama penelitian adalah sebesar 28,51 g/ekor/hari. Hasil penelitian ini sangat berbeda jauh dengan hasil penelitian Resti (2000) yang menggunakan amoniasi jerami padi terhadap performans domba memperoleh rataan PBBH sebesar 54,47 (g/ekor/hari). Namun hasil kedua penelitian ini sangat berbeda jauh dengan standar yang dikatakan oleh Sodiq dan Abidin (2002) yang menyatakan bahwa rataan PBBH domba yang bisa dicapai dengan pemeliharaan intensif adalah $0,2 \mathrm{~kg} / \mathrm{ekor} / \mathrm{hari}$ yang apabila dihitung dalam gram sebesar $200 \mathrm{~g} / \mathrm{ekor} / \mathrm{hari}$.

Rataan pertambahan bobot badan domba lokal jantan lepas sapih yang difermentasi MOL dan Trichoderma harzianum dengan masing-masing level 60\% dan 100\% memberikan pengaruh yang tidak berbeda nyata $(\mathrm{P}>0,05)$ terhadap domba local jantan lepas sapih.

Pertambahan bobot badan selama penelitian hanya 28,51 g/ekor/hari. Sementara apabila dilihat dari kandungan nutrisi yang di analisis dilaboratorium, eceng gondok fermentasi memiliki kandungan yang cukup tinggi yaitu kandungan protein eceng gondok yang difermentasi Trichoderma harzianum mencapai 19,56\%; Serat kasar 22,55\% eceng gondok fermentasi MOL adalah sebesar 9,79\%; Serat kasar 22,41\% sedangkan rumput kolonjono $8,86 \%$ dan serat kasar 21,39\%. Namun pertambahan bobot badan ini tidak hanya dilihat dari kandungan nutrisi saja tetapi juga dari tingkat palatabilitas yaitu adanya aroma eceng gondok fermentasi yang kurang baik mengakibatkan selera makan ternak menurun, sehingga tidak dapat memenuhi kebutuhan optimal ternak domba untuk memacu pertambahan bobot badan dari ternak domba. Hal ini sesuai dengan pernyataan Anggorodi 
(1990) yang menyatakan bahwa konsumsi pakan yang rendah akan menyebabkan kekurangan zat makanan yang dibutuhkan ternak dan akibatnya akan menghambat pertumbuhan lemak dan daging. Hal ini juga diikuti dengan pernyataan Church and Pond (1998) yang menyatakan bahwa pertambahan bobot badan yang diperoleh dari percobaan pada ternak merupakan hasil metabolisme zat-zat makanan yang dikonsumsi. Makin baik kualitas pakan yang dikonsumsi ternak maka akan diikuti oleh pertambahan bobot badan yang lebih tinggi.

Selain itu rataan pertambahan bobot badan ini juga dipengaruhi oleh umur domba yang masih sangat muda sehingga kondisi pencernaan masih sangat kecil dan bisa dikatakan masih dini untuk mengkonsumsi rumput dan eceng gondok fermentasi dalam penelitian ini yang pada akhirnya mempengaruhi pertambahan bobot badan. Hal ini sesuai dengan pernyataan Tomaszewska (1993), bahwa hal lain yang mempengaruhi laju pertambahan berat badan adalah umur, lingkungan dan faktor genetik, dimana berat tubuh pada awal fase penggemukan berhubungan dengan berat dewasa.

\section{Konversi Pakan}

Berdasarkan rataan konversi pakan yang diperoleh yaitu sebesar 15,44 dapat diasumsikan bahwa rumput kolonjono, eceng gondok fermentasi MOL dan Trichoderma harzianum tidak efisien digunakan sebagai bahan pakan ternak domba karena palatabilitasnya yang tidak baik. Selain itu nilai konversi pakan juga dipengaruhi oleh tingkat konsumsi dan nilai pertambahan bobot badan. Dalam penelitian ini rataan konsumsi pakan domba berkisar 402,69 sampai dengan 472,04 g/ekor/hari dan rataan pertambahan bobot badan berkisar 28,10 sampai dengan 28,93 g/ekor/hari.

Hasil analisis ragam menunjukkan bahwa pemberian eceng gondok yang difermentasi MOL dan Trichoderma harzianum memberikan pengaruh yang tidak berbeda nyata $(\mathrm{P}>0,05)$ terhadap domba lokal jantan lepas sapih.

Rataan nilai konversi pakan hasil penelitian ini jauh lebih tinggi dibandingkan dengan standar yang dikatakan Ishida dan Hasan (1993) yang menyatakan bahwa standar konversi pakan untuk domba adalah 8-10. Artinya untuk menaikkan $1 \mathrm{~kg}$ bobot badan domba dibutuhkan pakan sebanyak 8-10 kg. Berdasarkan rataan tersebut dapat diasumsikan bahwa penggunaan baik rumput kolonjono, eceng gondok fermentasi MOL dan Trichoderma harzianum tidak efisien digunakan sebagai bahan pakan ternak domba karena palatabilitasnya rendah. 
Pond et al., (1995) yang menyatakan bahwa konversi pakan pada ruminansia dipengaruhi oleh kualitas pakan, nilai kecernaan dan efisiensi pemanfaatan zat gizi dalam proses metabolisme didalam jaringan tubuh ternak. Makin baik kualitas pakan yang dikonsumsi ternak, akan diikuti oleh pertambahan bobot badan yang lebih tinggi dan makin efisien penggunaan pakannya. Hal ini juga sesuai dengan pernyataan Martawidjaja (1998) yang menyatakan bahwa kualitas pakan menentukan konversi pakan. Pakan yang berkualitas baik dapat menghasilkan pertambahan bobot badan yang tinggi. Penggunaan pakan akan semakin efisien bila jumlah pakan yang dikonsumsi rendah, namun menghasilkan pertambahan bobot badan yang tinggi.

\section{KESIMPULAN}

Pemanfaatan eceng gondok fermentasi MOL dan Trichoderma harzianum tidak memberikan pengaruh yang nyata terhadap konsumsi pakan, pertambahan bobot badan dan konversi pakan pada domba lokal jantan lepas sapih selama 4 bulan.

\section{DAFTAR PUSTAKA}

Anggorodi, R. 1990. Ilmu Makanan Ternak Umum. Gramedia, Jakarta

Church, D. And W. G. Pond. 1998. Digestive Physiology and Nutrient of Ruminant Vol 1. Departement of Animal Science Oragon State University Carvalis.

Direktorat Jenderal Bina Produksi Peternakan. 2006. Populasi Ternak Domba di Provinsi Sumatera Utara.

Dodiandri. 1997. Pengaruh Penggantian Sebagian Ransum Basal Dengan Eceng Gondok (Eichhornia crassipes) Atau Azolla (Azolla pinnata) Terhadap Daya Cerna Serat Kasar Dan Energi Termetabolisme Pada Ternak Itik Jantan Mojosari. Skripsi. Fakultas Peternakan. Universitas Andalas, Padang.

Ishida dan Hasan. 1993. Effects of Oil Palm Frond Silase Feeding on Utilization of diet and meat Production in Fattening Arton. Proc $86^{\text {th }}$ Annual Meeting of Jpn, Zootech, Sci, Iwate University.

Martawidjaja, M. 1998. Pengaruh Taraf Pemberian Konsentrat Terhadap Keragaman kambing Kacang Betina Sapihan. Pada: Prosiding Seminar Nasional Peternakan dan Veteriner. Balai Penelitian Ternak, Bogor.

Parakkasi, A., 1999. Ilmu Nutrisi dan Makanan Ternak Ruminansia. UI-Press, Jakarta.

Piliang, G.W., 2000. Fisiologi Nutrisi. Volume I. Bogor: Institut Pertanian Bogor.

Pond, W. G. and J. H. Maner. 1995. Sheep Production in Temperature and Tropical Environments. W. H. Freeman and Company. San Fransisco. 
Resti, M., 2000. Pengaruh Pemberian Berbagai Level Urea Pada Amoniasi Jerami Padi Terhadap Performans Domba Jantan Fase Pertumbuhan. Medan.

Sodiq, A. dan Z. Abidin. 2002. Penggemukan Domba. Angromedia Pustaka, Jakarta.

Steel R. G. D. dan J. H. Torrie. 1993. Prinsip dan Prosedur Analisis Suatu Pendekatan Biometrika. Edisi Kedua. Gramedia, Jakarta.

Tomaszewska, M. W., I. M. Mastika., A. Djajanegara., S. Gardiner dan T. R. Wiradarya., 1993. Produksi Kambing dan Domba di Indonesia. Sebelas Maret, Surabaya.

Williamson, G and W. J. A. Payne., 1995. Pengantar Peternakan di Daerah Tropis. UGMPress, Yogyakarta. 